\title{
Characteristics of Design Process Organization in Selected Furniture Manufacturing Companies
}

\section{Obilježja organizacije procesa dizajniranja proizvoda u odabranim tvrtkama za proizvodnju namještaja}

\author{
Original scientific paper • Izvorni znanstveni rad \\ Received-prispjelo: 8. 9. 2015. \\ Accepted-prihvaćeno: 6. 9. 2016. \\ UDK: $630 * 836.1$ \\ doi:10.5552/drind.2016.1532
}

\begin{abstract}
The aim of the study was to conduct and present an analysis for the characteristics of new products development process in selected furniture manufacturing companies, focusing on the competences and vocational training of individuals designing furniture. The results of survey conducted among 75 furniture factories were presented. The obtained data was elaborated statistically taking into consideration for example the size of the company. It was shown that designing of furniture in medium-sized and large enterprises is increasingly often performed by multidisciplinary design teams composed of designers and engineers. However, at the same time a vast number of furniture companies use the artistic talents of employed engineers. These results constitute an important signal, indicating the directions of changes for providing adequate education for students of engineering faculties of universities to meet modern market requirements.
\end{abstract}

Key words: design, furniture companies, new product development process

\begin{abstract}
SAŽETAK • Cilj istraživanja bio je provesti i prezentirati analizu procesa razvoja novog proizvoda u odabranim tvrtkama za proizvodnju namještaja, s naglaskom na kompetencije i stručno osposobljavanje osoba koje rade u procesu dizajniranja namještaja. Predstavljeni su rezultati ankete provedene u 75 tvrtki za proizvodnju namještaja. Dobiveni su podaci statistički obrađeni, pri čemu je uzeta u obzir, primjerice, veličina tvrtke. Pokazalo se da dizajniranje namještaja u srednjim i velikim poduzećima sve češće obavljaju multidisciplinarni dizajnerski timovi sastavljeni od dizajnera i inženjera. No istodobno se velik broj tvrtki za proizvodnju namještaja koristi umjetničkim talentima svojih inženjera. Dobiveni su rezultati važan pokazatelj kako je nužno promijeniti obrazovne ponude za studente tehničkih fakulteta kako bi se na odgovarajući način udovoljilo zahtjevima suvremenog tržišta rada.
\end{abstract}

Ključne riječi: dizajn, tvrtke za proizvodnju namještaja, proces razvoja novog proizvoda

\footnotetext{
${ }^{1}$ Author is associate professor at Poznan University of Life Sciences, Faculty of Wood Technology, Department of Furniture Design, Poznan, Poland.

${ }^{1}$ Autorica je izvanredna profesorica Sveučilišta bioloških znanosti u Poznanu, Fakultet drvne tehnologije, Zavod za dizajn namještaja, Poznan, Poljska.
} 


\section{INTRODUCTION}

\section{UVOD}

As a result of the high competition on the market, increasing attention is focused on the development of new products. This trend can also be observed in furniture industry. Enterprises, in order to effectively operate on the market, have to continuously change the assortment of their products, adapting them to consumers' expectations (Mruk and Rutkowski, 2001). Obviously, no product may be manufactured in an unchanged form for an arbitrarily long time. Enterprises, which intend to enjoy a long-term competitive edge, have to carefully observe changes occurring on the market and continuously modify their range of offered products (Krawiec, 2000; Rutkowski, 2006). These decisions are connected with the process of development of new products, including the withdrawal from the market, modification of already existing products or introduction of new products that determine the survival and development of the enterprise (Urban and Hauser, 1993; Stabryła, 2002; Rutkowski, 2006). It is increasingly difficult for enterprises to maintain their present position or reach a better, only by providing good quality products, or reducing their manufacturing costs. Easy access to modern technologies and their extensive use make it possible for most companies to manufacture a given product at a similar level of quality and manufacturing costs (Sosnowska, 2003). Therefore, enterprises should develop an innovative approach to processes of preparation and manufacture of products and orientation towards continuous work on updating the offered basket of goods. Considerable emphasis is placed not only on the reduction of the process of product preparation, but at the same time on the extension of the assortment of offered products and creation of products capable of meeting as best possible the growing needs of consumers. Additionally, globalization has resulted in a situation where companies more and more frequently operate on many markets and thus they have to differentiate the range of their products offered to consumers. Such a situation obviously requires the development of new ideas, and thus products and services. The creation of global companies has also resulted in the need to search for new, original ways of competing available for smaller enterprises, searching for market niches (Jerzyk et al., 2004). Contemporary enterprises tend to differentiate their products as much as possible. This objective may be reached thanks to the use of design, which is considered to be one of the most important factors influencing company activity in this field (Trueman and Jobber, 1998; Gemser and Leenders, 2001; Buil et al., 2005), enabling at the same time to gain the competitive advantage on the market.

The process of product development is also of crucial importance for furniture manufacturing companies. However, there is still a lack of research concerning this subject. The literature overview indicates that the analysis of implementation of design skills in furniture manufacturing companies was performed by Berginc et al. (2011) and Fabisiak (2011). Berginc et al.
(2011) presented the characteristics of the cooperation between furniture industry and designers with the focus on its strengths and weaknesses. Fabisiak (2011) studied the frequency of using design services, factors determining the cooperation with designers and the ways in which furniture manufacturing companies find new designers/design studios.

The aim of this paper is to conduct and present an analysis of the method for the preparation and development of new products in selected furniture factories, focusing on the competences and vocational training of individuals designing furniture.

\section{MATERIAL AND METHODS}

2. MATERIJAL I METODE

The investigation involved several selected furniture manufacturing companies located in Poland. The analysed sample of enterprises was selected on the basis of a quota selection method. It was divided into layers according to the following criteria: the level of employment and the geographical localisation so that the firms represented well the structure of furniture industry in Poland. In the described analysis, data from 75 enterprises were examined. The investigation was carried out using the survey method and direct interviews conducted at furniture manufacturers located in specific regions of Poland. The data collected were subjected to statistical analysis with the use of SPSS 16.0 and STATISTICA 10.0 PL software.

\section{RESULTS AND DISCUSSION} 3. REZULTATI I RASPRAVA

When analysing the organization of the process of furniture manufacturing, first of all, it should be established whether there is a department in the factory involved in designing of new products. Results of the investigation showed that $53 \%$ of analysed enterprises had a design department in their structure, while in the others it was most often combined with the engineering department. The main reasons for the decision not to have a separate design department, in case of most micro- and small enterprises, were economic considerations and occasionally even the fact that such investment "does not yield profits".

The graphic presentation of the performed statistical clustering indicates that the existence of the design department in an enterprise is connected with its size (Figure 1). It was stated that only $11 \%$ micro-enterprises and $30 \%$ small businesses had a design department. This dependence was far more advantageous in medium-sized and big enterprises, in which the discussed levels were $67 \%$ and $77 \%$.

The conducted correspondence analysis confirmed the results obtained using statistical clustering and the chi-square test. It needs to be stressed that the existence of the design department in enterprises is not a condition required for the achievement of the leading position on the market in terms of design application. For micro- and small enterprises, there are several al- 


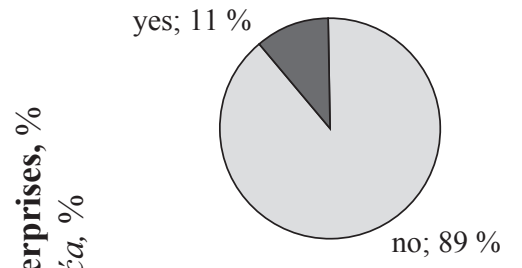

micro-companies mikro-poduzé́a

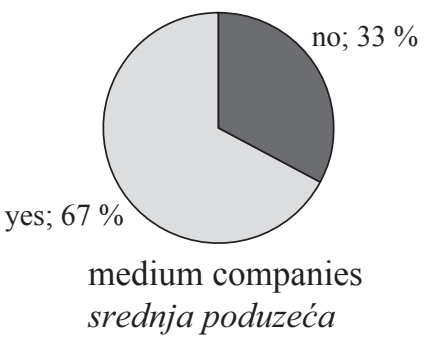

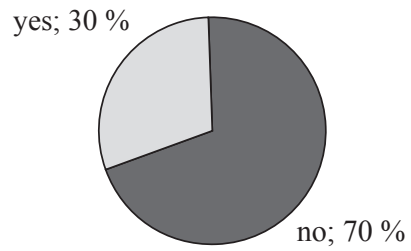

small companies mala poduzé́a

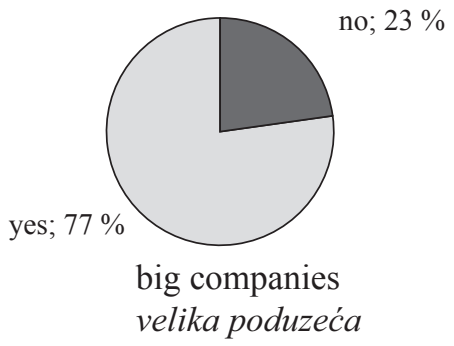

Design department / odjel za dizajn proizvoda

Figure 1 Structure of analysed furniture enterprises depending on the existence of a design department

Slika 1. Struktura analiziranih tvrtki za proizvodnju namještaja s obzirom na postojanje odjela za dizajn proizvoda

ternative solutions available. As previously mentioned, the design department may be combined with the engineering department or the performance of design services may be commissioned (outsourcing).

It was also decided to investigate if the existing globalization processes, and connected with them easier and faster transfer of knowledge, human resources and capital have impact on the number of foreign designers working for Polish companies. In order to gather that information, the nationality of furniture designers in the studied companies was defined. The results of the performed analysis showed that $37 \%$ of studied enterprises employed foreign designers or design studios. The detailed analysis, conducted within the companies employing foreign designers, revealed that this kind of investment was chosen mainly by big companies (Figure 2). However, it is worth to highlight that this group of companies included also medium, small and even micro-companies (Fabisiak, 2011).

Important information concerning the use of design in analysed companies is also supplied by the analysis of internal processes in designing and manufacturing of furniture, such as e.g. data on contractors, participants in these processes. They may be designers,

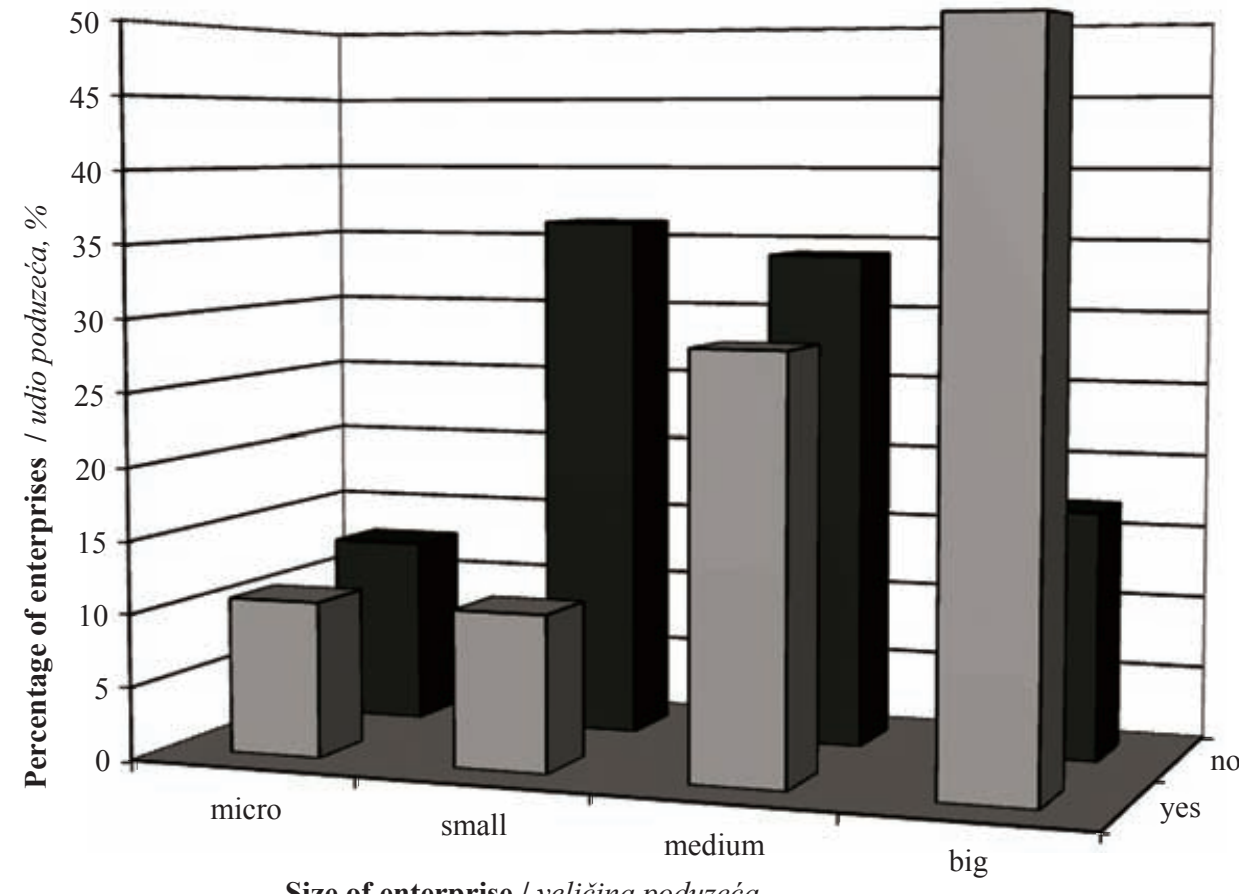

Size of enterprise / veličina poduzeća
Use of foreign design services korištenje vanjskih usluga dizajna

Figure 2 Structure of analysed furniture manufacturers in terms of the enterprise size and their use of services offered by foreign design agencies or designers

Slika 2. Struktura analiziranih tvrtki za proizvodnju namještaja s obzirom na veličinu tvrtke i korištenje uslugama inozemnih dizajnerskih agencija i dizajnera 


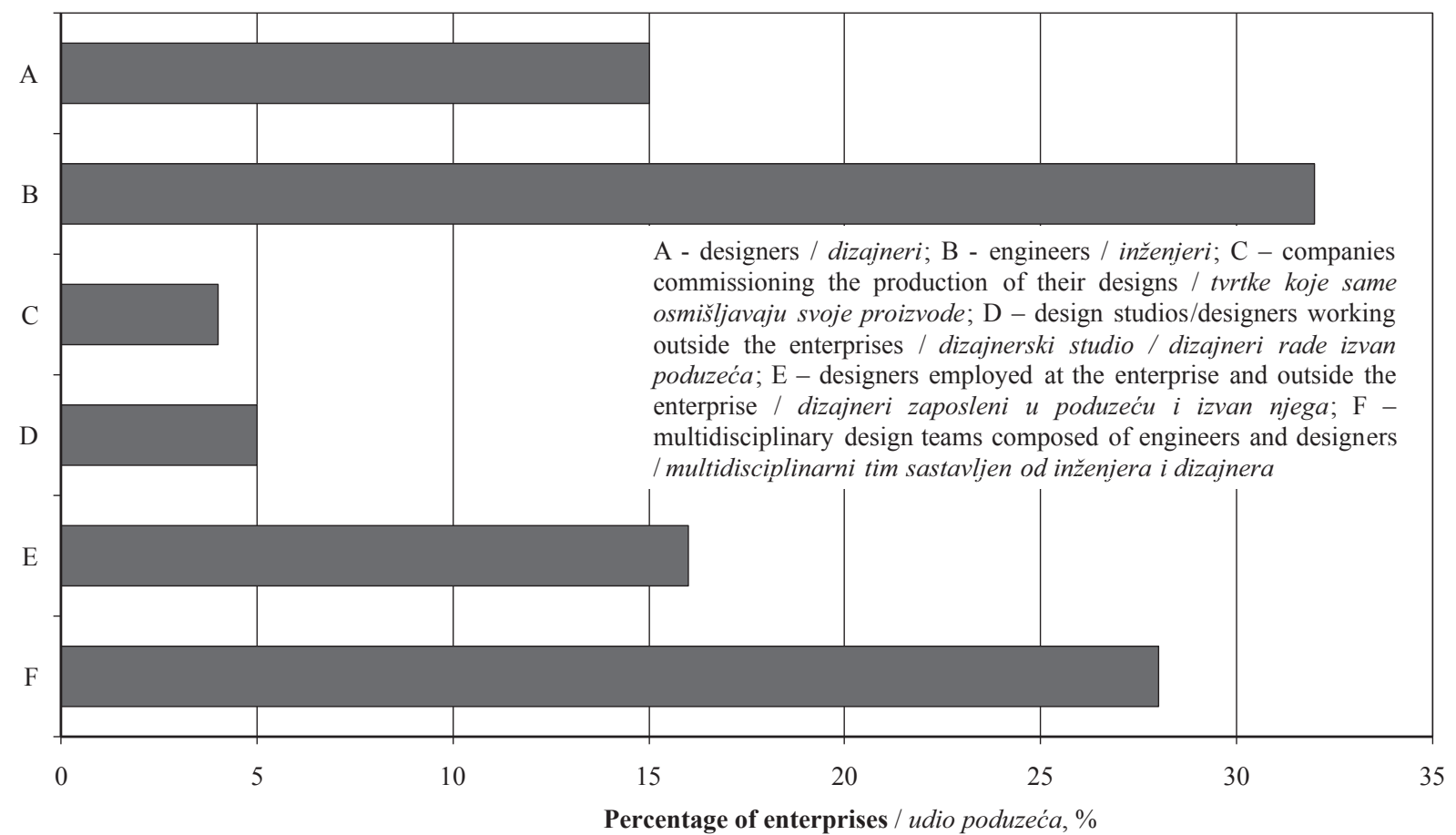

Figure 3 Structure of analysed furniture manufacturers depending on the group of design performers

Slika 3. Struktura analiziranih tvrtki za proizvodnju namještaja ovisno o tomu tko radi na dizajnu proizvoda

engineers, constructors, companies commissioning the production of their designs, design studios/designers working outside the enterprises, teams of designers employed at the enterprise and outside the enterprise, multidisciplinary design teams composed of engineers, design constructors and designers. Figure 3 presents the structure of examined enterprises depending on the groups mentioned above. The individual groups of design performers are labelled with A-F letters.

Based on the presented data, it can be noticed that engineers and constructors were responsible for creating projects of new furniture in $32 \%$ of examined enterprises. Furthermore, nearly $15 \%$ of companies employed designers and in $16 \%$ of furniture manufacturers

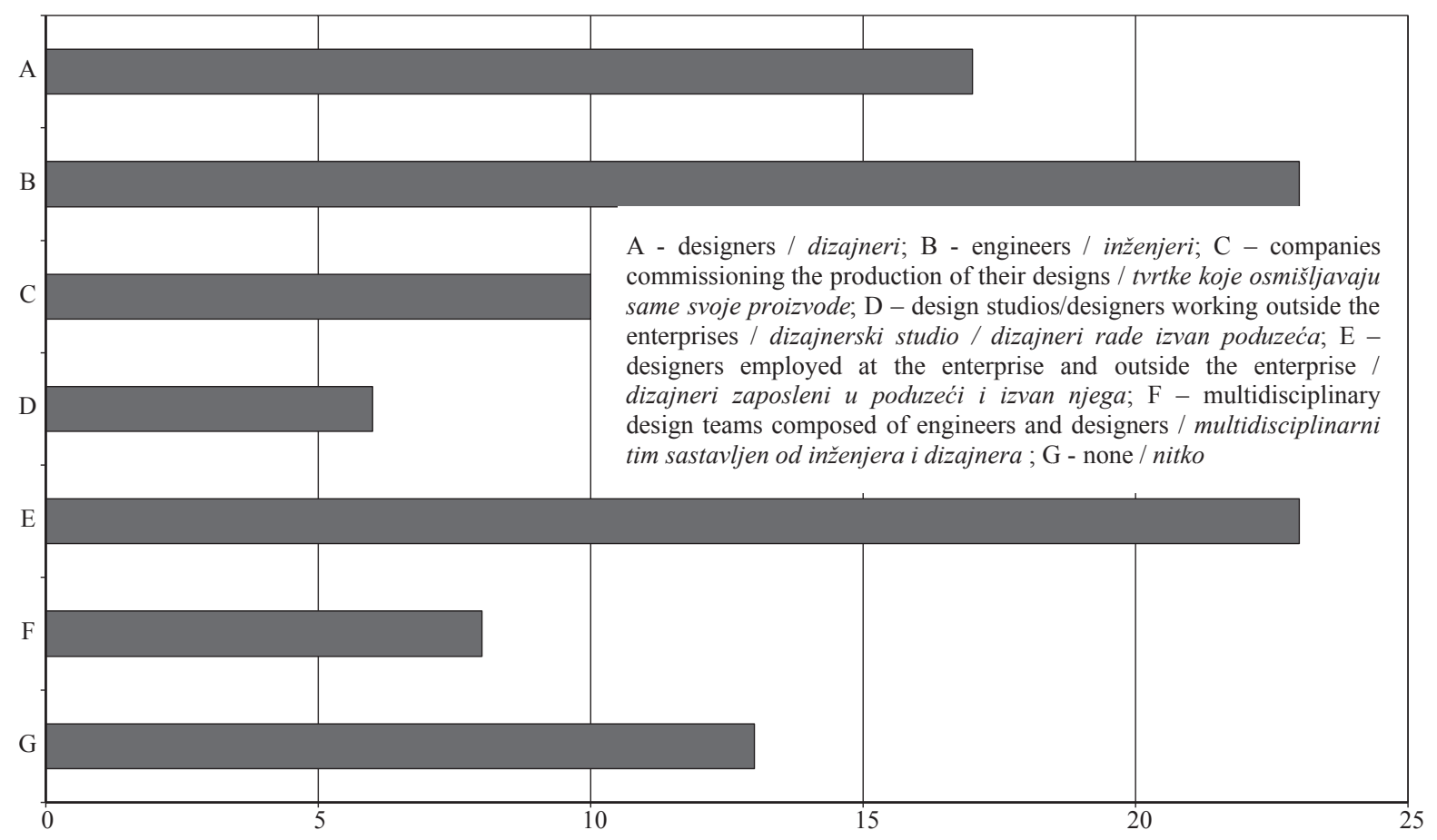

Percentage of enterprises / udio poduzeća, \%

Figure 4 Structure of analysed furniture enterprises depending on the type of design activity the enterprise plans to develop within 3 years since the period of the study

Slika 4. Struktura analiziranih tvrtki za proizvodnju namještaja ovisno o aktivnostima dizajniranja proizvoda koje tvrtka planira pokrenuti unutar tri godine od provedenog istraživanja 
design performers were both designers employed in the given company and external design studios. It is worth to highlight that often ( $28 \%$ of cases) a multidisciplinary team was responsible for the new product development. Only in $4 \%$ of cases, the analysed companies manufactured furniture only based on designs provided by companies commissioning the given production. Slightly over $5 \%$ of examined enterprises decided to invest in purchase of services offered by external design studios or designers.

The analysis of the organization of design activities in furniture factories also tried to determine in which direction managers of enterprises were planning to develop the design activities in their units (Figure 4).

It was found that $23 \%$ of companies are planning a development of design activities consisting in the use of both services of designers employed in the enterprise and design studios. The same percentage of enterprises intends to focus on engaging engineers and constructors employed in these companies in the process of furniture design. It also results from these investigations that $8 \%$ of enterprises will extend the work of design teams consisting of designers and engineers. These results constitute an important signal, on the basis of which it is possible not only to prepare an adequate education programme for students of engineering faculties of universities, but also offer curricula for graduate studies or even courses aimed at improving the skills in terms of aesthetic modification of furniture forms, computer aided design, the latest trends in design, ergonomics, functionality, and first of all work in a multidisciplinary design team.

It should be noted that only one enterprise among the small ones, the group of $11 \%$ of enterprises concerned, which declared the willingness to develop furniture design activity using designs supplied by other companies, intends to focus on the development of only this activity. The other factories, apart from the described activity, are also planning investments in other forms of organization of the process of creating furniture. This is a positive sign, since it implies that these companies will not create furniture only based on designs prepared by other enterprises, but rather attempt to design new collections themselves.

Based on statistical grouping method, analysis of directions of design activity development was performed depending on the enterprise size (Figure 5).

Half of the examined micro-enterprises plan to develop design activity using artistic talents of engineers employed in the company. It is also important to highlight that the group of companies not planning to develop any design activity was mostly made of microand small companies.

Analysis of the vocational training of individuals designing furniture in analysed enterprises showed that in $29 \%$ of factories the creation of new products was performed by graduates of the Faculty of Wood Technology, while in $17 \%$ of cases they were graduates of the Academy of Fine Arts (Figure 6). In the same group of companies, multidisciplinary design teams, consisting of graduates of the Academy of Fine Arts and the Faculty of Wood Technology or the University of Technology and the Faculty of Wood Technology, all from Poland, participated in the process of designing furniture. In $20 \%$ of factories, the vocational training of individuals designing furniture differed from the above mentioned education profiles. According to a detailed analysis of the discussed problem, conducted using the statistical clustering methods, it can be stated that such a situation was found mainly in micro- and small enterprises, where furniture design was conducted e.g. by company owners, who usually used their experience gained in the furniture sector. Multidisciplinary design teams were mostly characteristic of medium-sized and large-sized furniture factories.

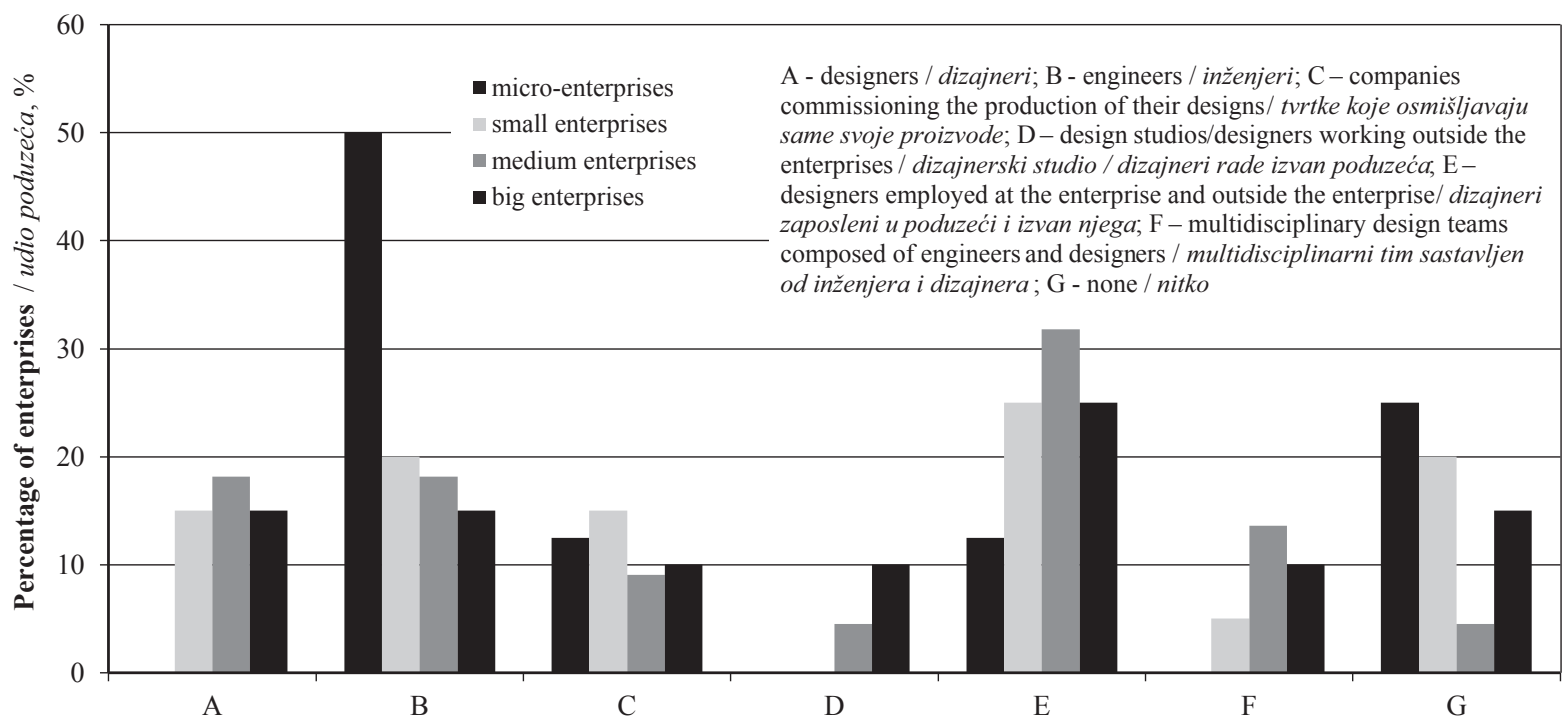

Figure 5 Structure of analysed furniture enterprises depending on the size of the enterprise and the type of design activity the enterprise plans to develop within 3 years since the period of the study

Slika 5. Struktura analiziranih tvrtki za proizvodnju namještaja ovisno o veličini tvrtke i aktivnostima dizajniranja proizvoda koje tvrtka planira pokrenuti unutar tri godine od provedenog istraživanja 


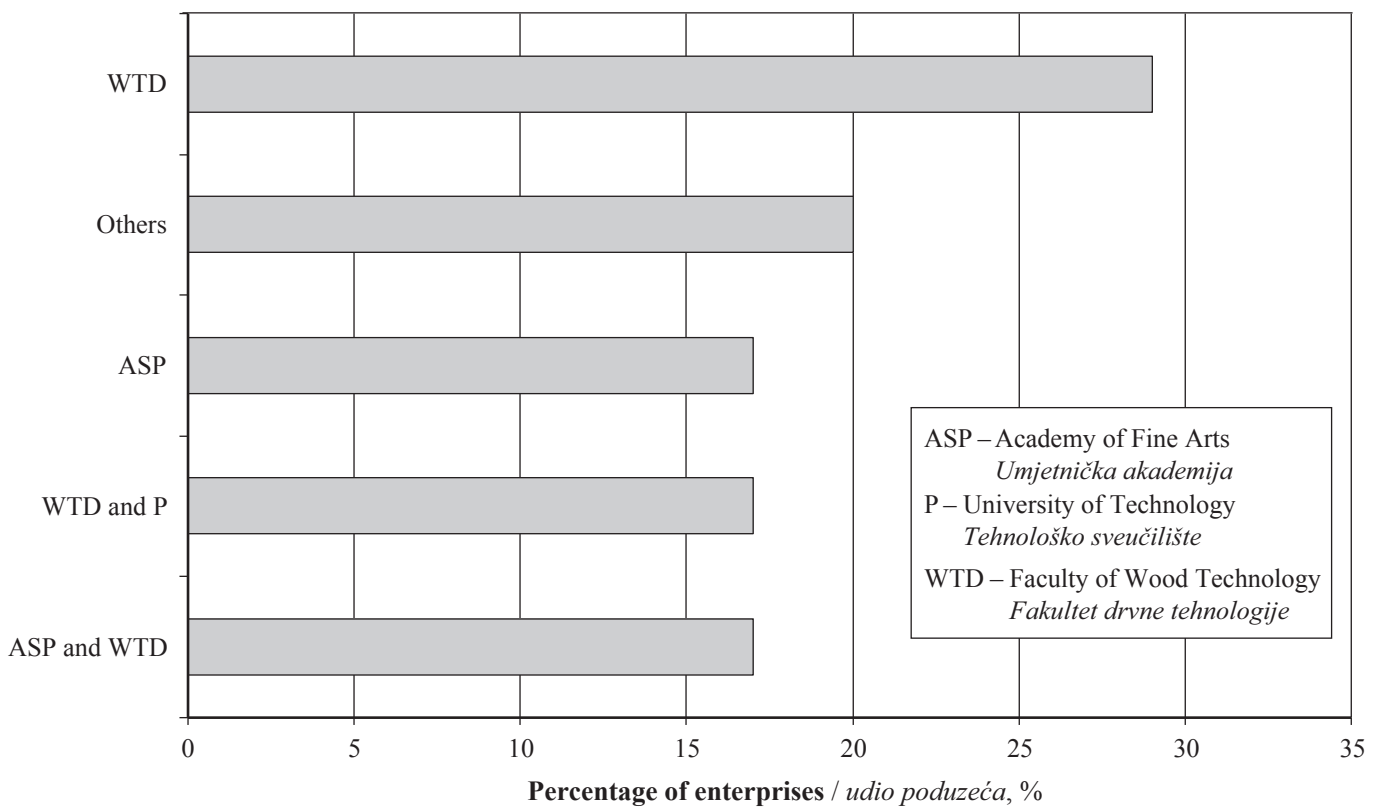

Figure 6 Structure of analysed furniture enterprises depending on the vocational preparation of individuals designing furniture

Slika 6. Struktura analiziranih tvrtki za proizvodnju namještaja ovisno o stručnoj osposobljenosti pojedinaca koji dizajniraju namještaj

The coexistence of individual variants of the discussed variables was analysed using the analysis of correspondence. Results were then verified using cluster analysis. The data presented in Table 1 indicate that the choice of 2 dimensional solution space allows to explain $92.2 \%$ of inertia. Moreover, the implementation of 2 dimensional solution space in the performed analysis was also indicated by the Cattell scree plot (Figure 7).

Graphic presentation of the results of the correspondence analysis indicates the occurrence of differences between 3 groups of enterprises depending on their size and vocational skills of individuals involved in furniture design (Figure 8). The first group is made of micro-enterprises, in which designing of furniture is usually performed by individuals with no university education in the field of design or manufacture of furniture. The second group is made of small and medium-sized enterprises, in which new furniture design is only prepared by designers - graduates of the Academy of Fine Arts or engineers graduated from the Faculty of Wood Technology. The third group is formed by large furniture factories, in which most typically multidisciplinary design teams, composed of graduates from different universities educating furniture designers and

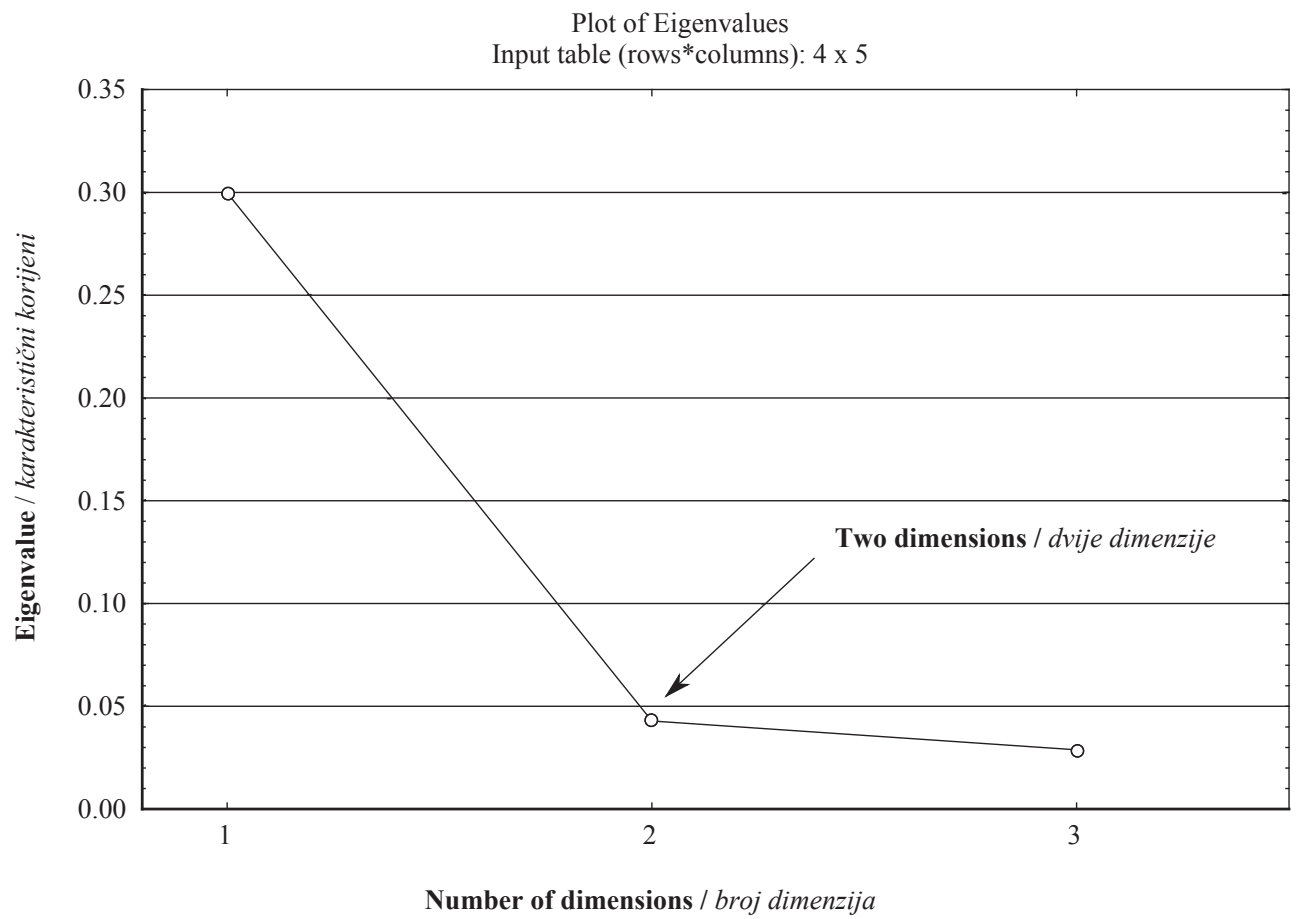

Figure 7 Scree plot for variables: size of company and educational background of individuals designing furniture Slika 7. Scree plot za varijable: veličina tvrtke i obrazovanje pojedinaca koji dizajniraju namještaj 
Table 1 Statistical characteristics of evaluation of choice of solution space for variables: size of company and educational background of individuals designing furniture

Tablica 1. Statističke vrijednosti procjene izbora rješenja za varijable: veličina tvrtke i obrazovanje pojedinaca koji dizajniraju namještaj

\begin{tabular}{|c|c|c|c|c|}
\hline $\begin{array}{c}\text { Number of } \\
\text { dimensions } \\
\text { Broj dimenzija }\end{array}$ & $\begin{array}{c}\text { Singular values } \\
\text { Singularne vrijednosti }\end{array}$ & $\begin{array}{c}\text { Eigen values } \\
\text { Karakteristični korijeni }\end{array}$ & $\begin{array}{c}\text { Percentage of inertia } \\
\text { Postotak inercije }\end{array}$ & $\begin{array}{c}\text { Cumulative } \\
\text { percentage } \\
\text { Kumulativni postotak }\end{array}$ \\
\hline 1 & 0.5475 & 0.2997 & 80.7017 & 80.7017 \\
\hline 2 & 0.2070 & 0.0429 & 11.5390 & 92.2407 \\
\hline 3 & 0.1698 & 0.0288 & 7.7593 & 100.0000 \\
\hline
\end{tabular}

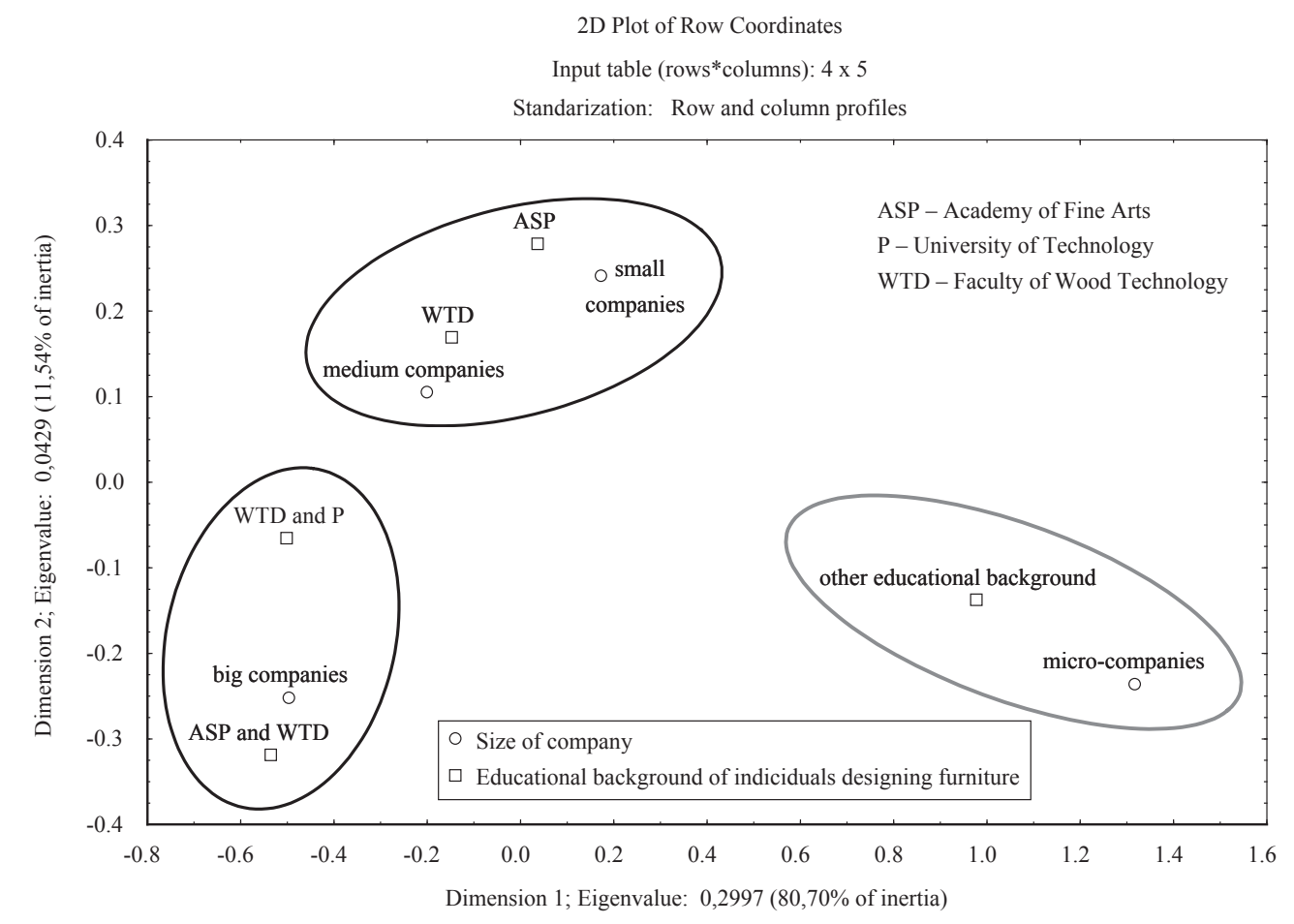

Figure 8 Graphic presentation of results of correspondence analysis of variables: size of enterprise and vocational training of individuals designing furniture

Slika 8. Grafički prikaz rezultata analize korespondencije za varijable: veličina tvrtke i stručno osposobljavanje pojedinaca koji dizajniraju namještaj

design engineers, are involved in the process of designing new products. The trend discussed above, connected with the vocational training of individuals designing new products in furniture enterprises, has also been observed in other European countries, e.g. in Portugal (Nogueira, 2008).

In order to verify the character of links between individual variants of analysed variables, a hierarchical classification was performed for cluster analysis according to Ward (Figure 9). Results of correspondence analysis were confirmed, and consequently 3 groups of co-existing traits were identified.

Furniture manufacturers participating in the study stressed the importance of cooperation of experts representing different fields in the process of designing and manufacturing furniture. It needs to be stressed that, already in the early 1990s, some studies (Potter et al., 1991; Walsh et al., 1992) indicated the correlation between a good design, good financial standing, and the use of multidisciplinary teams in the design process. These results are of great importance since the opinion is strengthening that the development of new products of the highest standard is only possible on the basis of cooperation between exerts representing a broad spectrum of specializations.

\section{CONCLUSIONS}

4. ZAKLJUČAK

To sum up, it may be concluded that the conducted analysis shows that designing of furniture in Polish medium-sized and large enterprises is increasingly often performed by multidisciplinary design teams composed of specialists - graduates of the Academy of Fine Arts, University of Technology or Faculty of Wood Technology from Poland. New designs of furniture in micro-enterprises are most commonly created by owners of these companies. A large proportion of furniture companies use the artistic talents of employed engineers and design engineers. The importance of the multidisciplinary character of the process of designing and manufacturing furniture has been outlined. These results constitute an important signal, on the basis of which an adequate education program may be developed, preparing graduates to work in a multidisciplinary design team. 


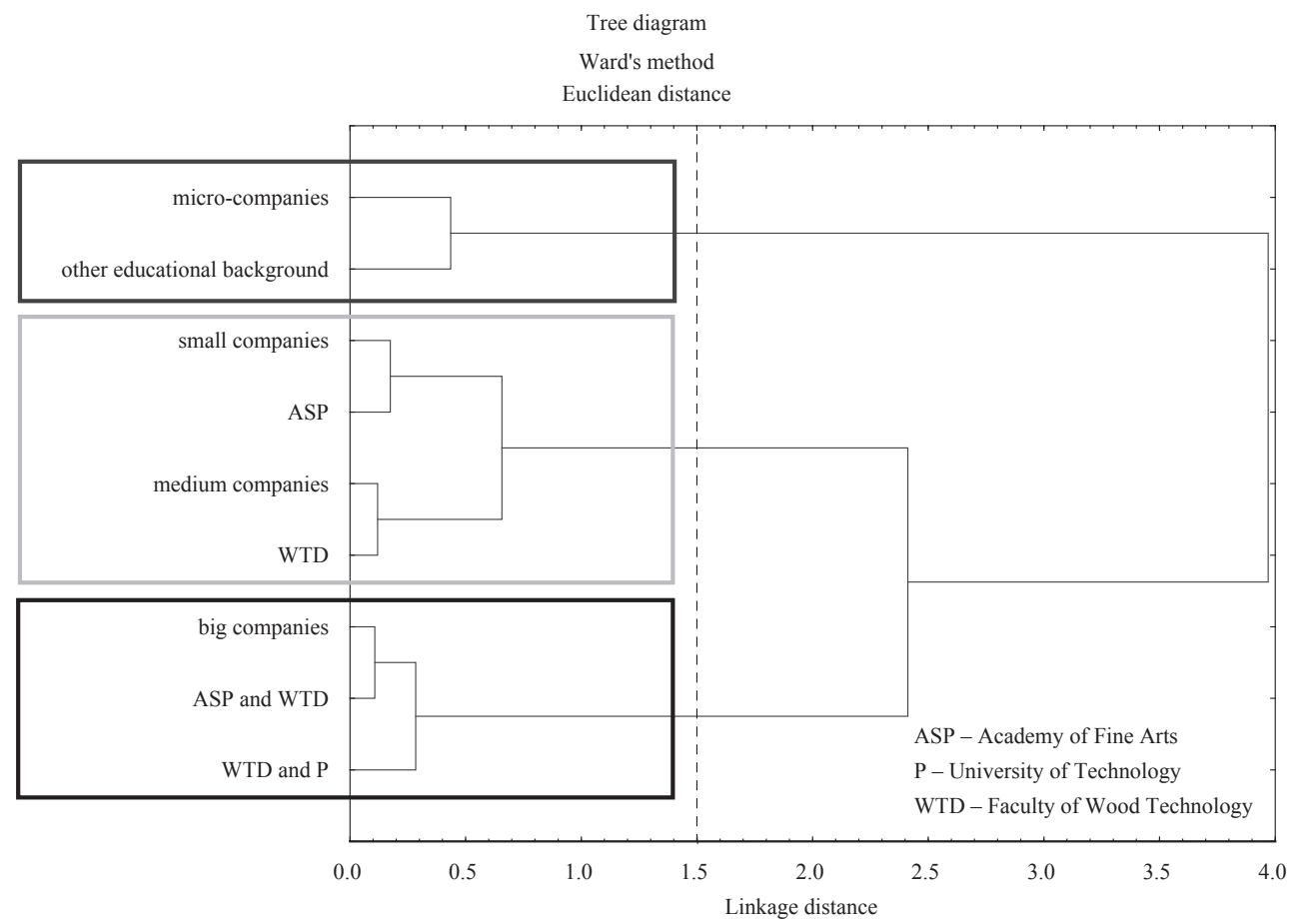

Figure 9 Graphic presentation of results of cluster analysis for variables: size of enterprise and vocational training of individuals designing furniture

Slika 9. Grafički prikaz rezultata klasterske analize za varijable: veličina tvrtke i stručno osposobljavanje pojedinaca koji dizajniraju namještaj

\section{REFERENCES}

\section{LITERATURA}

1. Berginc, J.; Hrovatin, J.; Feltrin, M.; Maechtig, S. J.; Zupančič, A.; Oblak, L., 2011: Analysis of cooperation between furniture industry and designers in product development process. Drvna industrija, 62: 129-136. http:// dx.doi.org/10.5552/drind.2011.1106.

2. Buil, I.; Martinem, E.; Montaner, T., 2005: Importancia del diseño industrial en la gestión estratégica de la empresa. Universia Business Review - Actualidad económica, Cuarto trimestre.

3. Fabisiak, B., 2011: The analysis of cooperation with designers in selected furniture companies. Ann Warsaw Univ Life Sci - SGGW For Wood Technol, 74: 46-51.

4. Gemser, G.; Leenders, M., 2001: How integrating industrial design in the product development process impacts on company performance. J Prod Innov Manage, 18 (1): 28-38. http://dx.doi.org/10.1016/S0737-6782(00)00069-2.

5. Jerzyk, E.; Leszczyński, G.; Mruk, H., 2004: Kreatywność w biznesie [Creativity in business]. Poznań, Poland: Wydawnictwo Akademii Ekonomicznej w Poznaniu (in Polish).

6. Krawiec, F., 2000: Zarządzanie projektem innowacyjnym produktu i usługi [Management of innovative product and service project]. Warszawa, Poland: Difin (in Polish).

7. Mruk, H.; Rutkowski, I. P., 2001: Strategia produktu [The product strategy]. Warszawa, Poland: Polskie Wydawnictwo Ekonomiczne (in Polish).

8. Nogueira, M. J., 2008: DME Award Meeting in Cieszyn, Poland, Centro Portuguese Design.

9. Potter, S.; Roy, R.; Capon, C. H.; Bruce, M.; Walsh, V.; Lewis, J., 1991: The Benefits and Costs of Investment in Design: Using Professional Design Expertise in Product, Engineering and Graphics Projects. The Open University/UMIST, Report Dig-03 Design Innovation Group.
10. Rutkowski, I., 2006: Metodyczne i kompetencyjne uwarunkowania rozwoju nowego produktu w przedsiębiorstwach przemysłowych [Methodical and competence conditionings of new product development in industrial enterprises]. Poznań, Poland: Wydawnictwo Akademii Ekonomicznej w Poznaniu (in Polish).

11. Sosnowska, A., 2003: Zarządzanie nowym produktem [Management of new product]. Warszawa, Poland: Oficyna Wydawnicza Szkoły Głównej Handlowej (in Polish).

12. Stabryła, A., 2002: Zarządzanie strategiczne w teorii i praktyce firmy [Strategic management in theory and company practice]. Warszawa, Poland: Wydawnictwo Naukowe PWN (in Polish).

13. Trueman, M.; Jobber, D., 1998: Competing through Design. Long Range Plann, 31 (4): 594-605. http://dx.doi. org/10.1016/S0024-6301(98)80052-6.

14. Urban, G. L.; Hauser, J. R., 1993: Design and Marketing of New Products. New Jersey, USA: Prentice Hall, Englewood Cliffs.

15. Walsh, V.; Roy, R.; Bruce, M.; Potter, S., 1992: Winning by design. Technology, product design, and international competitiveness. Oxford, UK: Blackwell Business Publishing.

\section{Corresponding address:}

Assoc. Prof. BEATA FABISIAK, Ph.D.

Department of Furniture Design

Faculty of Wood Technology

Poznan University of Life Sciences, Poland

Wojska Polskiego Street 38/42

60-637 Poznan, POLAND

e-mail: beata.fabisiak@up.poznan.pl 